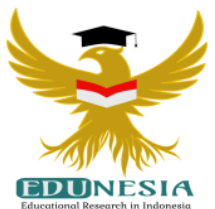

\title{
Praktik Pendidikan Agama Islam Berbasis Penguatan Karakter Religius dan Jujur di Lingkungan Full Day School
}

\author{
Mulyani Setyaningsih"; Ahmad Fikri Sabiq ${ }^{2}$ \\ 1,2Program Magister Pendidikan, Institut Agama Islam Negeri (IAIN) Salatiga, Indonesia \\ ${ }^{2}$ Corresponding Email: ahmadfikrisabiq@gmail.com, Phone Number :0823 xxxx xxxx
}

\author{
Article History: \\ Received: Agust 21, 2020 \\ Revised: Sept 03, 2020 \\ Accepted: Sept 06, 2020 \\ Published: Jan 01, 2021
}

\section{Keywords:}

Character of Religious and Honesty, Full Day School, Islamic Education.

\section{Kata Kunci:}

Full Day School, Karakter

Religius dan Jujur,

Pendidikan Agama Islam.

\section{How to cite:}

Setyaningsih, M., \& Sabiq, A.F. (2021). Praktik Pendidikan Agama Islam Berbasis Penguatan Karakter Religius dan Jujur di Lingkungan Full Day School. Edunesia : Jurnal Ilmiah Pendidikan, 2 (1): $10-22$

This is an open access article under the $C C-B Y-N C-N D$ license

\begin{abstract}
The purpose of this study is to determine the implementation of Islamic education based on religious and honest character in full day school. This research is a field research with a qualitative approach. The data collection techniques are interview, observation, and documentation. This research is located at SD Plus Tahfizhul Quran (PTQ) Annida Salatiga and the respondens are the principal, teachers, and parents of students. The analysis in this research is descriptive. The policy of strengthening the religious character and honest attitude of SD PTQ Annida Salatiga students is planned in a structured manner through planning programs and work programs. Religious and honest character is by carrying out the values contained in religious characters such as praying, praying, reading the Al-Qur'an and fasting. Strengthening the character of an honest attitude, namely muroja'ah book reports, children's prayer book reports, honesty not bringing pocket money, and pickets according to schedule. Implementation of this honest and religious character education program through intracurricular, co-curricular and extracurricular activities. These character education programs have positive results as same with parents' expectations
\end{abstract}

Abstrak: Penelitian ini bertujuan untuk mengetahui praktik pendidikan agama Islam berbasis penguatan karakter religius dan jujur di lingkungan full day school. Penelitian ini merupakan penelitian lapangan dengan pendekatan kualitatif. Teknik pengumpulan data yang digunakan peneliti adalah wawancara, observasi, dan dokumentasi. Penelitian ini berlokasi di SD Plus Tahfizhul Quran (PTQ) Annida Salatiga dengan narasumber adalah kepala sekolah, guru, dan orang tua siswa. Analisis dalam penelitian ini adalah deskriptif. Kebijakan penguatan karakter religius dan sikap jujur siswa SD PTQ Annida Salatiga direncanakan secara terstruktur melalui program perencanaan dan program kerja. Penguatan karakter religius dan jujur adalah dengan melaksanakan nilai-nilai yang terkandung dalam karakter religius seperti berdoa, ibadah sholat, membaca Al-Qur'an dan ibadah puasa. Penguatan karakter sikap jujur yaitu laporan buku muroja'ah, laporan buku sholat anak, kejujuran tidak membawa uang saku, dan piket sesuai jadwal. Pelaksaan program penguatan karakter religius dan jujur ini melalui kegiatan intrakurikuler, kokurikuler dan ekstrakurikuler. Program-program penguatan karakter ini memiliki hasil positif sesuai harapan orang tua. 


\section{A. Pendahuluan}

Pemerintah dalam merancang program sekolah berbasis karakter memiliki tujuan yang jelas, sebagaimana yang tertuang dalam Peraturan Presiden No. 87 Tahun 2017 yaitu untuk menanamkan nilai-nilai pembentukan karakter bangsa secara masif dan efektif. Penguatan pendidikan karakter ini dilakukan melalui implementasi nilai-nilai utama Gerakan Nasional Revolusi Mental yaitu religius, nasionalis, mandiri, gotong-royong, dan integritas yang fokus pada pembelajaran di sekolah, sehingga penguatan pendidikan karakter diharapkan dapat mengubah perilaku dan cara berfikir serta bertindak pada seluruh bangsa Indonesia (Kemdikbud 2017).

Dalam dunia pendidikan setiap pelayanan pendidikan semestinya memperhatikan perkembangan kepribadian setiap peserta didik. Karena, lewat pendidikan setiap orang mengharapkan agar anak memiliki perilaku yang baik. Orang-orang yang memiliki karakter baik dalam bersosialisasi adalah mereka yang memiliki akhlak, moral dan budi pekerti yang baik. Mengingat bahwa karakter ini sangat penting, maka lembaga pendidikan memiliki peran serta pula dalam penanamannya melalui proses pembelajaran.

Banyak lembaga pendidikan yang menghadirkan materi agama bagi para peserta didiknya agar bisa menjadi generasi yang memiliki karakter baik. Hal ini dilakukan juga untuk menjaga peserta didiknya dari ancaman degradasi moral seperti perkelahian anak sekolah, pencurian, pembunuhan, penggunaan narkoba, seks bebas, dan lain-lain. Sebagai contoh, berdasarkan data Badan Narkotika Nasional (BNN), ada 50-60\% remaja menjadi pengguna narkoba. Ada sekitar $48 \%$ dari jumlah tersebut merupakan pecandu sementara sisanya hanya mencoba-coba saja (kapanlagi.com 2017). Selanjutnya, dari data Unit PPA Nganjuk, pada tahun 2018 tercatat ada 55 kasus kenakalan remaja. Sedangkan pada tahun 2017 hanya ada 36 kasus. Ini artinya ada kenaikan hampir 50\%. Dari 55 kasus tersebut rinciannya adalah ada 8 kasus penganiayaan, 15 kasus pengeroyokan, 13 kasus pencurian, 18 kasus persetubuhan dan 1 kasus perjudian (detik.com 2018). Perbuatan-perbuatan inilah yang menimbulkan keresahan di dalam keluarga, sekolah dan masyarakat (Sudarsono 1991). Dalam sebuah penelitian disebutkan bahwa faktor-faktor yang mendominasi terjadinya degradasi moral sebagaimana di atas adalah karena kurangnya pemahaman dan penghayatan terhadap akhlak, semakin hilangnya nilai-nilai agama dalam kehidupan, semakin derasnya arus pergeseran atau dekadensi moral yang terjadi di kalangan masyarakat secara umum, serta hilangnya loyalitas terhadap Islam (Mahmud 2004).

Tidak hanya itu, saat ini pula kejujuran semakin terkikis. Seperti orang Jawa bilang "jujur malah ajur", jujur malah membuat hancur. Hal ini disebabkan ketidakjujuran telah sedemikian mewabah dan mempengaruhi sistem kehidupan secara keseluruhan, sehingga ketika ada orang yang jujur, dia justru akan terperosok dalam kesulitan. Jika ketidakjujuran telah menjadi sistem, masa depan bangsa ini akan suram. Hal ini dikarenakan ketidakjujuran menjadi penyebab lahirnya perilaku yang merugikan sendisendi kehidupan bangsa ini. Ketidakjujuran ini yang mendorong berkembangnya perilaku korupsi, kolusi, nepotisme, kekerasan, penipuan, dan sebagainya.

Oleh sebab itu pembentukan karakter perlu diupayakan dan diimplementasikan secara serius melalui jalur pendidikan baik formal maupun non formal. Secara psikologis, pembentukan karakter dalam diri individu merupakan fungsi dari seluruh potensi manusia meliputi kognitif, afektif, dan psikomotorik (Gunawan 2012). Dengan demikian implementasi pembentukan karakter dirasa sangat penting dalam rangka pembinaan generasi bangsa melalui lembaga pendidikan yang menggunakan berbagai upaya untuk 
menerapkannya, termasuknya penguatan pendidikan karakter yang dilakukan oleh sekolah yang menerapkan belajar seharian atau full day school.

Saat ini, sekolah yang menerapkan program full day school mengalami perkembangan yang pesat. Program ini dibuat untuk memaksimalkan pembinaan akhlak dan karakter yang baik pada peserta didik. Program ini tidak hanya memberikan pengetahuan saja, akan tetapi juga disertai pembentukan karakter agar peserta didik terbiasa melakukan perilaku-periilaku yang baik dan berakhlak dalam kehidupan seharihari. Program ini juga merupakan sebuah model pendidikan alternatif, dimana peserta didik sehari penuh berada di sekolah untuk melakukan proses pembelajaran dan proses beribadah. Dengan tersedianya waktu yang cukup lama di lingkungan sekolah peserta didik perlahan-lahan akan terbiasa dengan kehidupan berakhlak mulia, dan menumbuhkan sikap kebersamaan dan kesadaran beribadah serta sikap positif lainnya yang dapat menjadikan peserta didik menjadi lebih baik. Program tersebut juga dapat digunakan untuk mengembangkan kreativitas dan bakat yang dimiliki peserta didik.

Dalam sebuah penelitian, program Full Day School juga memberikan dampak positif pada sekolah dan peserta didik dimana pola hidup lebih tertata, kecerdasan emosional lebih baik, terbentuk kedisiplinan dalam belajar. Prestasi akademik mengalami kenaikan signifikan dibandingkan dengan kondisi sebelumnya saat menggunakan sistem reguler (Leasa and Batlolona 2017). Dengan demikian, ada nilai plus yang menjadi kelebihan dari program full fay school dibandingkan program reguler yang tidak menerapkan full day school.

Di Salatiga, salah satu sekolah yang menerapkan sistem full day school adalah SD Plus Tahfizhul Quran (PTQ) Annida. Sekolah ini menjadi pilihan penelitian ini karena merupakan sekolah yang memiliki program khusus berupa hafalan Al-Qur'an. Hal ini juga untuk memperkuat kajian tentang praktik pendidikan agama Islam yang di dalamnya terdapat pendidikan karakter, termasuknya karakter religius dan kejujuran. Peneliti ingin menggali konsep dan informasi berkaitan dengan implementasi penguatan pendidikan karakter religius dan kejujuran melalui praktik pendidikan agama Islam pada full day school di SD Plus Tahfizhul Quran (PTQ) Annida.

\section{B. Metode}

Penelitian ini merupakan penelitian lapangan dengan pendekatan kualitatif. Teknik pengumpulan data yang digunakan peneliti adalah wawancara, observasi, dan dokumentasi. Penelitian ini mengambil lokasi di SD Plus Tahfizhul Quran (PTQ) Annida Salatiga, yang merupakan salah satu unit pendidikan di bawah naungan Yayasan Annida Salatiga. Narasumber penelitian adalah kepala sekolah, guru, dan orang tua/wali siswa. Dalam penelitian ini, siswa tidak menjadi narasumber dikarenakan siswa adalah sebagai obyek penelitian. Analisis dalam penelitian ini adalah deskriptif yaitu memaparkan apa yang terdapat atau terjadi di lapangan yang terkumpul kemudian diklasifikasikan atau dikelompok-kelompokkan menurut jenis, sifat, atau kondisinya dan kemudian ditarik kesimpulan (Arikunto 2010). Dengan kata lain, data yang telah dikelompokkan tersebut kemudian disusun kembali menjadi rangkuman inti sesuai dengan tema. Proses analisis kemudian dilakukan penelitian dengan mengembangkan rangkuman tersebut menjadi paparan yang mendalam berdasarkan pemahaman peneliti selama proses pengumpulan data sampai menemukan esensi dari fenomena yang diteliti. Peneliti menjelaskan secara sistematis dan logis tentang bagaimana fenomena itu terjadi. Untuk membantu agar 
peneliti mampu menganalisis data secara mendalam dengan penjelasan yang tepat, peneliti dapat mengakaji kepustakaan, mengkonfirmasi temuan dengan teori yang telah ada sebelumnya (Mulyaningsih 2014).

\section{Hasil dan Pembahasan}

Pemberlakuan Undang-Undang Nomor 32 Tahun 2004 tentang Pemerintahan Daerah menuntut pelaksanaan otonomi daerah dan wawasan demokrasi dalam penyelenggaraan pendidikan. Pengelolaan pendidikan yang semula bersifat sentralistik berubah menjadi desentralistik. Kewenangan pengelolaan pendidikan desentralistik diberikannya kepada sekolah untuk menyusun kurikulumnya dengan mengacu pada Undang-Undang Nomor 20 Tahun 2003 tentang Sistem Pendidikan Nasional. Bentuk nyata dari desentralisasi pengelolaan pendidikan ini adalah diberikannya wewenang kepada sekolah untuk mengambil keputusan berkenaan dengan pengelolaan pendidikan, seperti dalam pengelolaan kurikulum, baik dalam penyusunannya maupun pelaksanaannya di sekolah.

SD Plus Tahfizhul Quran (PTQ) Annida berdiri sejak tahun 2013 dan didesain dengan menerapkan sistem full day school. Model ini diadaptasi dari beberapa lembaga sekolah berbasis Al-Qur'an dari berbagai daerah. Diharapkan dengan berdirinya sekolah tersebut dapat memberikan tambahan pilihan masyarakat dalam memilih lembaga pendidikan, memiliki nilai plus dan berbasis qur'an bagi anak mereka. Pendirian sekolah ini juga untuk mengembalikan kebesaran dan khittoh pondok pesantren Annida sebagai pengalir kehidupan agama sebagaimana spirit yang dibawa oleh $\mathrm{KH}$. Ali As'ad (alm) selaku pendiri pondok pesantren.

Visi dari sekolah ini yaitu melahirkan hafizh-hafizhah Al-Qur'an yang berprestasi, berkarakter, berwawasan kebangsaan, dan berkepribadian Qur'ani terampil mandiri. Selanjutnya, visi ini terjabarkan dalam misi yaitu menyelenggarakan pendidikan berbasis tahfizhul qur'an dengan target 10 juz, mengembangkan potensi dan prestasi anak anak didik dalam berbagai bidang bakat dan minat, menanamkan dan mengintegrasikan nilainilai karakter pada setiap unsur pendidikan, sekolah bersendikan nilai-nilai Islam, pancasila, dan kewawasan kebangsaan, serta memiliki tujuan dapat meghasilkan output kepribadian siswa yang qur'ani, terampil dan mandiri (Sabiq 2020a).

SD Plus Tahfizhul Quran (PTQ) Annida ini memiliki program-program unggulan dan ciri khas tertentu yaitu tahfizh quran 10 juz, sholat dhuha setiap akan memulai pelajaran, istirahat tidur siang, dua guru di setiap kelas, dan lagu tilawah berupa lagu Muri-Q yang digunakan agar metode menghafal lebih mudah diterima anak. Selain itu juga ada outing class yang dilaksanakan untuk menambah wawasan siswa, kegiatan malam bina iman dan taqwa (mabit) untuk melatih anak mandiri dan disiplin dalam melaksanakan kegiatan keagamaan, dan tasmi' untuk menunjang program hafalan AlQur'an (Sabiq 2020b). Sekolah ini juga sekolah yang berbasis karakter, sehingga selain memiliki pengetahuan umum dan hafalan Al-Qur'an, anak-anak diharapkan memiliki akhlak yang baik. Karakter merupakan kecenderungan hati atau sikap dalam merespon sesuatu serta bentuk perilakunya. Dalam bahasa agama, karakter itu pada hakekatnya adalah akhlak, karakter yang baik disebut akhlak al karimah, sedangkan karakter yang buruk disebut akhlak al-madhmumah (Zaenal 2014).

Menurut Thomas Lickona, karakter berkaitan dengan konsep moral (moral knowing), sikap moral (moral feeling), dan perilaku moral (moral behavior) (Lickona 1991). 
Berdasarkan tiga komponen ini dapat dinyatakan bahwa karakter yang baik didukung oleh pengetahuan tentang kebaikan. Thomas Lickona juga mengatakan bahwa:

How our schools can teach respect and responsibility "down throught history, in countries all over the world, education has had two great goals: to help young people become smart and to help them become good" (Lickona 1991).

Dari kutipan tersebut, pendidikan memiliki peran membantu anak menjadi pintar dan menjadi baik. Menjadikan peserta didik cerdas dan pintar, boleh jadi mudah melakukannya, tetapi menjadikan peserta didik agar menjadi orang yang baik, tampaknya jauh lebih sulit.

Berdasarkan nilai-nilai agama, pancasila, budaya dan tujuan pendidikan nasional, ada delapan belas yang perlu dikembangkan dalam pendidikan karakter, diantaranya yaitu religius dan kejujuran (Kosim 2011). Dua hal inilah yang akan menjadi fokus penelitian ini. Nilai religius merupakan sikap dan perilaku yang patuh dalam melaksanakan ajaran agama yang dianutnya, toleran dalam pelaksanaan agama lain, dan hidup rukun dengan pemeluk agama lain (Kemendiknas 2010).

Berkaitan dengan hal ini, Raymond F. Paloutzin menyebutkan:

Religious behavior has been defined at the individual, group, or societal levels. religion has been conceived of as being either whatever fulfills religious functions for the person or group or a partiuclar content or substance which the person or group expounds and the which they adhere (Paloutzian 1996).

Religius mencerminkan perilaku keagamaan yang dipatuhi. Nilai karakter religius meliputi tiga dimensi relasi, yaitu hubungan antara individu dengan Tuhan, individu dengan sesama, dan individu dengan lingkungan (Sriwilujeng 2017).

Selanjutnya, perilaku jujur merupakan salah satu wujud keimanan. Jujur juga merupakan petunjuk yang paling kuat atas keberadaan iman di dalam hati pelakunya, ketercapaian tujuannya dan sebagai penuaian apa yang dia minta dan kewajiban yang dia bebankan (Fattah 2001). Pentingnya penerapan sebuah kejujuran pada diri siswa melalui pembelajaran yaitu untuk melatih kebiasaan sejak dini agar kedepannya menjadi lulusan yang tidak hanya berkompeten dalam pengetahuan semata melainkan juga memiliki kepribadian yang arif.

SD Plus Tahfizhul Quran (PTQ) Annida didesain dengan sistem full day school dengan kurikulum semi pesantren. Model ini diadaptasi dari beberapa lembaga sekolah dasar atau madrasah ibtidaiyah yang berbasis Al-Qur'an. Dalam silabus dan RPP memuat SK, KD, tujuan pembelajaran, strategi dan metode pembelajaran semuanya itu berdasar dalam pembentukan karakter siswa (Yulianti 2020). Sebagai contoh, dalam silabus di SD PTQ Annida ini setiap mata pelajaran yang diajarkan semuanya berisikan karakter siswa yang diharapkan berdasar penguatan karakter : dapat dipercaya (trustworthines), rasa hormat dan perhatian (respect), tekun (diligence), tanggung jawab (responsibility), berani (courage), ketulusan (honesty), integritas (integrity), peduli (caring) dan jujur (fairnes) (Yulianti 2020).

Pendidikan karakter ditanamkan dalam pendidikan Islam bertujuan agar tercipta peserta didik yang memiliki akhlakul karimah. Penanaman karakter pada anak perlu ditanamkan sejak anak usia dini selain dari pembinaan perkembangan jasmani anak, untuk mendukung tujuan dari pendidikan tersebut. Integrasi pendidikan karakter dalam pembelajaran dilaksanakan agar peserta didik dapat menguasai kompetensi (materi) yang ditargetkan, serta mampu menginternalisasikan nilai-nilai yang didapat dan mempraktikkannya dalam kehidupan sehari-hari. 
Pada prinsipnya semua mata pelajaran dapat digunakan sebagai alat untuk mengembangkan karakter peserta didik. Namun, tidak semua materi cocok untuk semua nilai karakter, oleh karena itu perlu adanya sinkronisasi antara materi dengan nilai-nilai karakter yang akan diberikan. Integrasi pendidikan karakter dilakukan pada penginternalisasi nilai-nilai di dalam tingkah laku yang dilakukan guru setiap hari dalam proses pelaksanaan pembelajaran. Misalnya untuk penguatan karakter religius dan sikap jujur yang tertanam dalam diri anak maka harus ada kegiatan-kegiatan pembiasaan yang dilakukan, seperti sholat dhuha dan wajib berjamaah, serta para guru diminta untuk selalu memberikan anak-anak motivasi tentang penguatan karakter dengan menyelipkan dalam pembelajaran (Yulianti 2020).

Pendidikan yang berkarakter mampu menanamkan nilai-nilai karakter pada peserta didik sebagai fondasi agar terbentuknya generasi yang berkualitas yang mampu hidup mandiri dalam kehidupan sehari-hari. Harapannya adalah peserta didik bisa menjadi manusia berakhlak yang memiliki prinsip suatu kebenaran yang dapat dipertanggung jawabkan. SD PTQ Annida sebagai sekolah yang berkarakter dalam prosesnya telah merencanakan dan melaksanakan model penguatan pendidikan karakter religius dan sikap jujur sejak awal berdiri (Sabiq 2020b).

Penguatan pendidikan karakter dilakukan dengan berbagai kegiatan. Pertama, kegiatan intrakurikuler atau kegiatan belajar mengajar. Di dalam aspek kegiatan intrakurikuler ini, penanaman pendidikan karakter religius dan jujur dilaksanakan melalui proses pembelajaran yang termuat di dalam Rencana Pelaksanaan Pembelajaran (RPP) dan melalui pembiasaan-pembiasaan yang ada di sekolah. Jadi, di dalam RPP ini dimasukkan nilai-nilai karakter dengan diintegrasikan pendidikan karakter dalam materi pelajaran. Misalnya, saat memulai dan selesai kegiatan pembelajaran, siswa diajak untuk berdoa bersama, mengucapkan salam saat pamitan keluar atau masuk kelas. Ini merupakan contoh dari penanaman karakter religius kepada siswa. Guru juga menyampaikan pembelajaran dengan bahasa santun dan berperilaku sopan. Kemudian, setiap pagi anak-anak diajarkan untuk melaksanakan shalat Dhuha serta shalat dzuhur dan ashar secara berjamaah (Yulianti 2020).

Secara khusus, di sekolah ini memiliki program tambahan berupa hafalan AlQur'an. Selama enam tahun, siswa ditarget bisa hafal Al-Qur'an sebanyak 10 juz. Siswa juga ada program berupa baca tulis Al-Qur'an yang berguna untuk menunjang hafalan AlQur'an. Untuk menunjang kegiatan ibadah dan kebiasaan mengaji Al-Qur'an ini, sekolah membuat buku penghubung antara sekolah dengan orang tua yang tujuannya adalah untuk memastikan bahwa siswa juga melaksanakan program-program tersebut di rumah. Buku ini diisi oleh orang tua yang dalam waktu seminggu sekali akan diperiksa oleh guru. Ini juga merupakan program pendidikan karakter religius dan jujur yang diberikan kepada siswa. Siswa harus bisa mempertanggungjawabkan isi buku penghubung tersebut bahwa isi buku tersebut sesuai dengan realita yang dilakukan oleh siswa di rumah.

Selanjutnya, penanaman karakter dalam pembelajaran di kelas pada setiap materi pelajaran atau kegiatan dirancang khusus sehingga kegiatan belajar mengembangkan kemampuan dalam ranah kognitif, afektif, dan psikomotorik. Pengintegrasian pendidikan karakter dalam semua materi pelajaran secara eksplisit dan implisit sudah ada dalam rumusan kompetensi dalam standar inti. Pengintegrasian nilai karakter dalam materi pembelajaran ini diharapkan memiliki dampak positif dan berbanding lurus dengan pembentukan karakter siswa. 
Guru di kelas sebagai fasilitator memiliki peran yang sentral dalam melaksanakan, menerapkan, dan mendukung ketercapaian pendidikan karakter di sekolah. Pelaksanaan dengan keteladanan guru, selain menyampaikan materi pembelajaran, guru dalam pembelajaran dikelas juga berperan sebagai teladan bagi peserta didik (Hasanah 2020).

Selanjutnya, berdasarkan penelusuran dokumen RPP Pendidikan Agama Islam berbasis penguatan karakter religius dan sikap jujur memasukkan nilai-nilai pendidikan karakter dengan melihat kompetensi dasar PAI yang diajarkan di SD PTQ Annida Salatiga yaitu karakter religius ibadah sholat, karakter religius membaca Al-Qur'an dan karakter religius ibadah puasa.

Tabel 1.

Nilai Karakter Religius

\begin{tabular}{|c|c|c|c|}
\hline & Nilai Karakter Religius & Kompetensi Dasar & Indikator \\
\hline 1 & $\begin{array}{l}\text { Karakter religius ibadah } \\
\text { sholat } \\
\text { (dalam RPP kelas } 2 \text { dan 3) }\end{array}$ & $\begin{array}{l}\text { Melakukan sholat } \\
\text { dengan benar }\end{array}$ & $\begin{array}{l}\text { Melafalkan dan } \\
\text { menghafalkan bacaan } \\
\text { sholat dengan benar, } \\
\text { mempraktekkan gerakan } \\
\text { sholat dengan benar }\end{array}$ \\
\hline 2 & $\begin{array}{l}\text { Karakter religius mambaca } \\
\text { Al-Qur'an } \\
\text { (dalam RPP kelas 4) }\end{array}$ & $\begin{array}{l}\text { Membaca surah Al- } \\
\text { Lahab dan Al-Kafirun }\end{array}$ & $\begin{array}{l}\text { Membaca Surah Al-Falaq } \\
\text { dan Al-Fil dengan harakat } \\
\text { dan makhraj yang benar, } \\
\text { mengulang-ulang } \\
\text { membaca Surah Al-Falaq } \\
\text { dan Al-Fil dengan harakat } \\
\text { dan makhraj yang benar, } \\
\text { mengartikan dan } \\
\text { menghafal surah Al-Falaq } \\
\text { dan Al-Fil dengan benar }\end{array}$ \\
\hline 3 & $\begin{array}{l}\text { Karakter religius ibadah } \\
\text { puasa } \\
\text { (dalam RPP kelas 5) }\end{array}$ & $\begin{array}{l}\text { Menyebutkan ketentuan } \\
\text { dan hikmah puasa } \\
\text { ramadhan dan puasa } \\
\text { sunnah }\end{array}$ & $\begin{array}{l}\text { Menjelaskan pengertian } \\
\text { puasa Ramadan, } \\
\text { Menyebutkan ketentuan- } \\
\text { ketentuan puasa Ramadan } \\
\text { dan puasa sunah, } \\
\text { Mempraktikkan puasa } \\
\text { Senin dan Kamis }\end{array}$ \\
\hline
\end{tabular}

Di dalam dokumentasi RPP di atas, karakter religius ditunjukkan dengan contoh anak-anak diminta untuk membaca dan menghafal surah Al-Falaq dan Al-Fil sebagai bagian dari mata pelajaran Pendidikan Agama Islam. Setelah itu guru menerangkan hukum bacaan tersebut dan melafalkan sesuai makhraj dan harakat yang benar serta mempelajari dan mendiskusikan isi pokok surah Al-Falaq dan Al-Fil tersebut. Ini merupakan salah satu dari pendidikan karakter religius yang diterima oleh siswa.

Selanjutnya adalah nilai karakter jujur yang ada di SD Plus Tahfizhul Quran (PTQ) Annida Salatiga sebagai berikut: 
Tabel 2.

Nilai Karakter Sikap Jujur

\begin{tabular}{|c|c|c|c|}
\hline No & $\begin{array}{l}\text { Nilai Karakter Sikap } \\
\text { Jujur }\end{array}$ & Kompetensi Dasar & Indikator \\
\hline 1 & Laporan buku muroja'ah & $\begin{array}{l}\text { Membaca surah yang } \\
\text { ditugaskan oleh guru }\end{array}$ & $\begin{array}{l}\text { Menyampaikan laporan } \\
\text { sesuai apa adanya }\end{array}$ \\
\hline 2 & Laporan buku sholat anak & Sholat tepat waktu & $\begin{array}{l}\text { Menyampaikan laporan } \\
\text { sholat sesuai apa adanya }\end{array}$ \\
\hline 3 & $\begin{array}{l}\text { Jujur tidak membawa } \\
\text { uang saku saat ke sekolah }\end{array}$ & $\begin{array}{l}\text { Menerapkan sikap tidak } \\
\text { boros dan jujur }\end{array}$ & $\begin{array}{l}\text { Menjelaskan kenapa kita } \\
\text { tidak boleh boros dan } \\
\text { kenapa harus bersikap } \\
\text { jujur }\end{array}$ \\
\hline 4 & $\begin{array}{l}\text { Piket sesuai dengan } \\
\text { jadwal }\end{array}$ & $\begin{array}{l}\text { Menyelesaikan tugas } \\
\text { piket }\end{array}$ & Melatih tanggung jawab \\
\hline
\end{tabular}

Selanjutnya, contoh teladan sikap jujur seperti saat akan sholat ditanya anak sudah berwudhu atau belum, saat akan makan siang anak-anak disuruh ambil lauk sesuai dengan jatah masing-masing, monitoring hafalan di rumah dilaksanakan atau tidak, dan sholat di rumah dilaksanakan atau tidak. Semua itu ada di buku penghubung sebagai monitoring kegiatan anak di rumah. Hal ini sesuai dengan hasil wawancara, observasi, dan dokumentasi yang menunjukkan bahwa guru berusaha memberikan contoh atau keteladanan religius dan sikap jujur dalam pembelajaran di kelas. Beberapa dokumentasi dan hasil observasi juga menggambarkan kegiatan-kegiatan guru di kelas yang menunjang ketercapaian aplikasi model penguatan pendidikan karakter di SD PTQ Annida Salatiga (Hasanah 2020). Hal ini sesuai dengan perilaku jujur yang merupakan komponen ruhani yang memantulkan berbagai sikap terpuji (honorable, respectable, creditable, maqaman mahmuda). Perilaku yang jujur adalah perilaku yang diikuti dengan sikap tanggung jawab atas apa yang dia perbuatnya. Dia siap menghadapi risiko dan seluruh akibatnya dengan penuh sukacita (Inten 2017).

Kedua, kegiatan kokurikuler atau kegiatan pendukung kegiatan intrakurikuler yang juga terencana dan tertuang di dalam kalender pendidikan. Kegiatan kokurikuler dilaksanakan guna untuk menambah wawasan peserta didik dan penguatan karakter pendidikan secara langsung guna mendukung kegiatan intra sekolah yang berkaitan dengan tema-tema pembelajaran di telah dilakukan maka SD PTQ Annida mengadakan outhing class setiap semester sekali seperti yang telah dilaksanakan yaitu berkunjung ke kebun binatang, ketempat pengolahan limbah kotoran sapi yang bisa dipergunakan untuk bio gas, bermain air ke muncul dan senjoyo dan tempat-tempat edukasi lainnya yang berkaitan dengan tema yang telah dipelajari (Hasanah 2020).

SD PTQ Annida juga memberikan tambahan jam pembelajaran kepada anak-anak yang kurang dalam pembelajaran dan bagi anak-anak yang membutuhkan yang biasanya dari permintaan orang tua atau dari inisiatif wali kelas. Tambahan jam pelajaran tersebut dilaksanakan pada jam saat anak-anak jadwal tidur siang atau bisa sore hari tergantung dengan permintaan. Selain itu untuk melatih kemandirian anak, wawasan keagamaan, membangun semangat muroja'ah, melatih kedisiplinan dan tanggung jawab peserta didik, maka SD PTQ Annida merencanakan kegiatan setiap semester sekali malam bina iman dan taqwa atau mabit (Hasanah 2020). 
Ketiga, melalui kegiatan ekstrakurikuler. Kegiatan ekstrakurikuler adalah kegiatan yang bertujuan memberikan kesempatan kepada peserta didik untuk mengembangkan dan mengekspresikan diri sesuai dengan kemampuan, bakat, dan minat siswa. Adapun kegiatan-kegiatan yang telah terprogram dan terencana sesuai dengan jadwal kegiatan seperti Pramuka yang bertujuan untuk melatih jiwa kepemimpinan yang beriman, bertaqwa dan berwawasan ilmu pengetahuan dan teknologi. Selain itu juga untuk membentuk sikap dan perilaku yang positif, menguasai keterampilan dan kecakapan serta memiliki ketahanan mental, moral, spiritual, emosional, sosial, intelektual, dan fisik. Nilai pendidikan karakter religius dalam ekstrakurikuler pramuka ini terletak pada implementasi Dasa Dharma Pramuka nomor satu yaitu "Takwa kepada Tuhan Yang Maha $E s a^{\prime \prime}$. Di dalam kegiatan Pramuka, siswa sering diajak mengikuti kegiatan perkemahan yang dilaksanakan di alam terbuka. Kegiatan ini menjadi bagian ujian bagi siswa terkait dengan pelaksanaan ibadah ketika sedang berada di luar rumah atau di luar sekolah. Siswa akan diuji apakah ketika berada di luar rumah atau sekolah ini, mereka masih tetap melaksanakan ibadah dengan tertib yang tentunya tetap didampingi oleh pembina Pramuka. Sedangkan nilai karakter jujur dalam ekstrakurikuler Pramuka terletak pada implementasi Dasa Dharma Pramuka nomor sembilan yang berbunyi "Bertanggung jawab dan dapat dipercaya." Dalam kegiatan Pramuka, siswa sering ada penugasan-penugasan yang harus dikerjakan. Berkaitan dengan hal ini, siswa dilatih untuk jujur atas apa yang dia kerjakan. Ini merupakan contoh pelaksanaan program pendidikan karakter religius dan jujur yang ada di dalam kegiatan Pramuka.

Selain itu juga ada kegiatan ekstrakurikuler tilawah Al-Qur'an bertujuan untuk melatih anak-anak agar dalam pembacaan al qur'an dapat lancar dan benar, menyempurnakan bacaan yang salah, dan dapat menyebarluaskan ilmu al qur'an kepada peserta didik. Kegiatan kaligrafi dan menggambar bertujuan untuk menumbuh kembangkan potensi bakat seni anak, menciptakan spiritual dalam diri anak, melalui keindahan kaligrafi dan gambar yang dibuat dapat belajar bahwa kita dapat memahami tentang keagungan pada Sang pencipta.

Dari kegiatan-kegiatan yang telah terprogram tersebut intinya semua bertujuan untuk mengembangkan bakat peserta didik. Kegiatan tersebut dilaksanakan setiap hari sesuai jadwal pada jam anak-anak tidur siang dan anak-anak diminta untuk memilih salah satu kegiatan dari beberapa program tersebut.

Selanjutnya, dalam pelaksanaan program penanaman karakter religius dan sikap jujur di SD PTQ Annida banyak melibatkan peran orang tua yaitu saling kerjasama dalam mendidik anak. Dalam wawancara dengan seorang narasumber menyatakan bahwa:

"Kegiatan sekolah dalam rangka penguatan karakter religius dan sikap jujur melibatkan orang tua, seperti halnya ada buku yang diberikan sekolah untuk diisi orang tua di rumah yaitu buku mutaba'ah (buku pengawasan) tentang kegiatan hafalan Al-Qur'an anak, sholat anak di rumah, bahkan sampai kegiatan membantu orang tua. Dengan buku ini orang tua akan lebih mudah dalam membimbing anak di rumah. Anak juga terbiasa sholat tepat waktu dimasjid, bersikap sopan dan taat kepada orang tua dan mau puasa. Dalam penanaman sikap jujur anak sering saya minta untuk bercerita saat di sekolah ada kejadian apa, dan biasanya anak berkata jujur, sehingga hal ini akan membuat anak terbiasa terbuka dan jujur dalam hal apapun" (Yulianti 2020).

Dan wawancara dengan salah satu narasumber memberikan tambahan dalam sikap jujur yaitu sebagai berikut: 
"Di sekolah anak tidak boleh membawa uang saku, dan anak saya pun menuruti aturan sekolah dengan tidak membawa uang saku. Apabila minta uang dengan saya itu saat untuk berinfaq saja" (Istiqomah 2020).

Dalam menyelenggarakan kegiatan-kegiatan untuk penguatan karakterpun SD PTQ Annida juga melibatkan peran serta orang tua, baik di rumah maupun di sekolah. Seperti contohnya yang berkaitan dengan penguatan karakter religius saat di rumah ada buku mutaba'ah yang dibawa anak untuk diisi orang tua yaitu berisikan kegiatankegiatan anak di rumah, seperti isian hafalan qur'an, sholat saat di rumah, kegiatan membantu orang tua, dan ada pesan dari guru untuk setiap setelah maghrib untuk muroja'ah hafalan bersama orang tua. Dalam hal ini, orang tua yang menjadi mitra utama dari sekolah/guru memiliki beberapa tugas atau peran yang harus dilakukan. Pertama, memahami tentang maksud dan bentuk kerjasama antara sekolah dengan orang tua. Sosialisasi tentang program kerjasama ini dilaksanakan pada awal tahun pelajaran dengan cara menghadirkan orang tua ke sekolah.

Kedua, mendampingi anak-anaknya untuk mengikuti program dari sekolah. Orang tua berperan penting untuk pendampingan ini selama anak berada di rumah karena pelaksanaan pendidikan karakter dan kurikulum ini dilaksanakan di sekolah dan di rumah. Hal ini selaras dengan konsep tiga pusat pendidikan, yaitu sekolah, keluarga/rumah, dan lingkungan masyarakat. Ketiga, tugas orang tua selanjutnya adalah mengisi buku penghubung atau buku mutaba'ah. Pengisian buku ini menjadi penting karena akan menjadi pengendali program.

Berkaitan dengan tugas orang tua ini, ada beberapa hal yang menjadi evaluasi bersama. Pertama, tidak semua orang tua bisa mendampingi dikarenakan kesibukan masing-masing yang beragam. Kedua, tidak semua orang tua mengisi buku penghubung sebagai alat kontrol kegiatan siswa di rumah (Sabiq 2020b). Dari evaluasi ini, perlu adanya komunikasi dan keseriusan dari orang tua untuk melaksanakannya.

Sedangkan dalam penguatan karakter sikap jujur, anak selalu ditanya kegiatan selama di sekolah apa saja yang diajarkan guru dan apa saja yang terjadi di sekolah biasanya anak akan bercerita apa adanya dan terbuka dalam bercerita. Hal tersebut maka dapat mendukung penanaman sikap jujur pada anak dalam hal apapun. Saat di sekolah juga dalam penanaman sikap jujur ada peraturan dari sekolah, misalnya anak tidak boleh membawa uang saku. Mereka boleh membawa hanya untuk berinfaq saja dan anak-anak mematuhi hal tersebut.

Upaya komunikasi dan keakraban antara orang tua dan sekolah, maka SD PTQ Annida Salatiga membuat forum yaitu Persatuan Orang Tua Murid dan Guru (POMG) dan grup Whatsapp. Seperti paparan seorang narasumber dari wali murid yaitu:

"Saya mendukung semua program sekolah karena itu dapat membantu anak-anak dalam pembentukan karakter dengan pembiasaan kehidupan sehari-hari yang menjadikan anak menjadi terbiasa. Serta untuk terlaksananya program sekolah maka dibuatlah forum bersama sekolah dan orang tua yaitu adanya komunikasi yang ingin cepat mendapat respon dengan adanya grup Whatsapp dan POMG yang diadakan rutin setiap bulan sekali yang didalamnya ada seminar parenting yang diisi oleh ahli-ahli pendidikan" (Yulianti 2020)

Selama berjalannya pembelajaran di sekolah banyak peningkatan yang didapat anak yaitu seperti yang disampaikan salah satu narasumber: 
"Anak saya dulu waktu sebelum masuk di SD PTQ Annida Salatiga sholat masih sering diingatkan, membaca Al-Qur'annya masih kurang lancar, hafalan Al-Qur'annyapun masih berada di juz 30, namun setelah anak saya belajar di SD PTQ Annida salatiga selama 5 tahun ini sudah banyak capaiannya yaitu membaca Al-Qur'annya dengan tajwid yang benar dan lancar, sudah hafal 9 juz lebih, berakhlak baik, lebih mengetahui mana yang baik dan mana yang buruk, serta sholat dan puasanya tidak pernah bolong" (Yulianti 2020).

Organisasi sekolah tidak akan efektif apabila interaksi di antara orang-orang yang tergabung dalam sekolah tidak pernah ada komunikasi. Komunikasi menjadi sangat penting karena merupakan aktivitas mencurahkan waktu untuk menginformasikan sesuatu dengan cara tertentu kepada seseorang atau sekelompok orang. Dengan komunikasi, maka fungsi manajerial yang berawal dari perencanaan, implementasi dan pengawasan dapat dicapai (Sutapa 2006).

Komunikasi dapat dipahami sebagai sarana penyampaian pesan, informasi, atau pemikiran ide-ide dari satu orang atau lebih kepada orang lain atau kelompok orang dengan menggunakan lambang yang sama.

Komunikasi yang terjadi di sekolah dilaksanakan baik internal sekolah aupun eksternal sekolah. Komunikasi internal sekolah dilakukan oleh warga sekolah di dalam lingkungan sekolah, sedangkan eksternal sekolah dilaksanakan terkait dengan komunikasi sekolah dengan masyarakat seperti orang tua, alumni, masyarakat pemerintah, ataupun lembaga yang menjalin kerjasama dengan sekolah.

Untuk sarana komunikasi antara sekolah dan orang tua/wali murid yang berhubungan dengan kegiatan pembelajaran anak di sekolah maupun di rumah, maka sekolah memberikan fasilitas sarana komunikasi yaitu melalui grup Whatsapp per kelas serta buku monitoring. Sehingga saat terjadi sesuatu di sekolah maupun ada kesulitan orang tua tentang informasi sekolah dari anak bisa langsung yang efektif lewat grup wa kelas. Dan untuk memantau hasil kegiatan anak bisa dilihat dari isian di buku monitoring anak.

Perjalanan kesuksesan sebuah lembaga formal tidak bisa terlepas dari dukungan orang tua untuk mewujudkan visi dan misi sekolah. Oleh karenanya sinergitas kerjasama antara sekolah dan orang tua selaku wali murid menjadi sangat penting. Hal itulah yang menjadikan alasan diadakannya forum Persatuan Orangtua Murid dan Guru (POMG) di SD PTQ Annida Salatiga. Sebagai stakeholder penting, wali murid sejatinya merupakan penanggung jawab utama atas pendidikan yang didapatkan oleh putra-putrinya. Selain itu orang tua/wali murid mengatas namakan sebuah keluarga merupakan satu dari segitiga emas pendidikan, selain tentunya sekolah dan masyarakat.

POMG tersebut dibuat sebagai sarana keakraban antara sekolah dan orang tua serta dalam setiap pertemuan diisi pula dengan acara seminar parenting keluarga untuk mencapai tujuan bersama yang dilaksanakan setiap bulan sekali. Selain sarana keakraban dengan sekolah dalam persatuan tersebut juga sering mengadakan kegiatan-kegiatan sosial seperti membantu bencana di Palu dan Donggala.

Orang tua dalam mendidik anak pastilah memiliki harapan-harapan peningkatan yang besar terhadap perkembangan baik fisik maupun kepribadian anak. Dengan menyekolahkan anak mereka di SD PTQ Annida Salatiga banyak sekali harapan yang orang tua inginkan seperti dalam hal beragama anak memiliki akhlak/kepribadian yang mulia, anak hafal al qur'an, disiplin sholat dan mau menjalankan puasa. Sedangkan 
peningkatan dalam akademik anak mampu mengikuti mata pelajaran sesuai dengan tingkatannya.

Capaian-capaian siswa di SD PTQ Annida menurut responden sudah mengalami peningkatan. Yang dulunya sebelum masuk di SD PTQ Annida susah dalam kedisiplinan sholat menjadi disiplin dalam sholat, yang dulunya belum lancar membaca Al-Qur'an dan belum benar tajwidnya menjadi lancar dala membaca dan sesuai dengan tajwidnya, yang dulunya hafalan masih juz 30 saja dan ada yang kurang sekarang meningkat menjadi hafal 2 juz, 5 juz, dan bahkan sampai 9 juz dalam al qur'an. Sehingga orang tua merasa senang dan tambah semangat dalam memotivasi anak dalam belajar serta orang tuapun jadi ikut belajar al qur'an, agar dalam mendampingi belajar anak lebih nyaman dan percaya diri.

Dari capaian tersebut, agar anak dapat lebih semangat dan senang, guru bisa menyiapkan reward atau hadiah berupa apapun itu yang bisa menjadi kenang-kenangan dan kebanggan siswa. Namun guru di SD PTQ Annida belum ada pemberian reward berupa barang yang bisa menjadi kenang-kenangan bagi siswa yang akan diingat sampai kelak.

\section{Kesimpulan}

Kebijakan penguatan karakter religius dan sikap jujur siswa SD PTQ Annida Salatiga direncanakan secara terstruktur melalui berbagai perencanaan dan program kerja. Penguatan karakter religius dan sikap jujur di SD PTQ Annida Salatiga adalah dengan melaksanakan nilai-nilai yang terkandung dalam karakter religius seperti berdoa, ibadah sholat, membaca Al-Qur'an dan ibadah puasa. Penguatan karakter sikap jujur yaitu laporan buku muroja'ah, laporan buku sholat anak, kejujuran tidak membawa uang saku, dan piket sesuai jadwal. Pelaksaan program penguatan karakter religius dan jujur ini melalui kegiatan intrakurikuler, kokurikuler dan ekstrakurikuler. Program-program penguatan karakter ini memiliki hasil positif sesuai dengan yang disampaikan orang tua bahwa dalam penanaman penguatan karakter anak sudah baik, diantaranya yang anaknya dulu tidak bisa membaca Al-Qur'an dengan lancar, sekarang jadi lancar dan dengan tajwid yang benar. Dulu susah untuk disiplin sholat menjadi mau sholat walau terkadang orang tua mengingatkan berulang-ulang. Dulu puasa tidak rutin namun sekarang menjadi rutin berpuasa, dan walau ada pula yang puasanya juga masih ada yang bolong namun biasanya itu ada pada anak kelas bawah.

\section{Daftar Pustaka}

Arikunto, S. 2010. Prosedur Penelitian; Suatu Pendekatan Praktik. Jakarta: Rineka Cipta.

detik.com. 2018. "Kenakalan Remaja Di Nganjuk Meningkat 50 Polisi Blusukan Ke Sekolah." Detik.Com.

Fattah, M. S. 2001. Jujur Menuju Jalan Yang Benar. Yogyakarta: Bintang Cemerlang.

Gunawan, H. 2012. Pendidikan Karakter: Konsep Dan Implikasinya. Bandung: Alfabeta.

Hasanah, N. 2020. “Implementasi Pendidikan Karakter." 
Inten, D.N. 2017. "Penanaman Kejujuran Pada Anak Dalam Keluarga." Jurnal Familyedu 3(1):35-45.

Istiqomah. 2020. "Praktik Pendidikan Karakter Di Sekolah."

kapanlagi.com. 2017. "Fenomen Klitih Potret Kenakalan Remaja Yang Mengkhawatirkan." Kapanlagi.Com.

Kemdikbud. 2017. Penguatan Pendidikan Karakter. Jakarta: Dirjen PTK Kemdikbud.

Kemendiknas. 2010. Bahan Pelatihan Penguatan Metodologi Pembelajaran Berdasarkan NilaiNilai Budaya Untuk Membentuk Daya Saing Dan Karakter Bangsa. Jakarta: Balitbang Kemendiknas.

Kosim, M. 2011. “Urgensi Pendidikan Karakter." Karsa : Journal of Social and Islamic Culture 9(1):89.

Leasa, M., and Batlolona, J.R. 2017. “Full Day School Dalam Pembentukan Karakter Siswa SMKN 13 Kota Malang." Jurnal Ilmu Sosial Dan Humaniora 6(1):73-82.

Lickona, T. 1991. Educating for Character How Our Schools Can Teach Respect and Responsibility. New York: Bantam Books.

Mahmud, A. A. 2004. Akhlak Mulia. Jakarta: Gema Insani.

Mulyaningsih, E. 2014. Metode Penelitian Terapan Bidang Pendidikan. Bandung: Alfabeta.

Paloutzian, R. F. 1996. Invition to the Psychology of Religion. USA: Allyn \& Bacon.

Sabiq, A.F. 2020a. "Hubungan Antara Kematangan Beragama Dan Kematangan Kepribadian Dengan Sikap Toleransi Pada Guru SD PTQ Annida Salatiga Tahun 2020." IAIN Salatiga, Salatiga.

Sabiq, A.F. 2020b. “Implementasi Pendidikan Karakter.”

Sriwilujeng, D. 2017. Panduan Implementasi Penguatan Pendidikan Karakter. Jakarta: Erlangga.

Sudarsono. 1991. Etika Islam Tentang Kenakalan Remaja. Jakarta: Rineka Cipta.

Sutapa, M. 2006. "Membangun Komunikasi Efektif Di Sekolah." Jurnal Manajemen Pendidikan 2(2):69-72.

Yulianti, A. 2020. “Implementasi Pendidikan Karakter."

Zaenal, A. 2014. Islamic Character Building. Jakarta: Grafindo Media Pratama. 